\title{
DENOLOGIA. SŁOWO WSTĘPNE
}

\author{
PIOTR SKALSKI, BARTOSZ WÓJCIK
}

Dwa teksty, które publikujemy w tym numerze Praktyki Teoretycznej, są rezultatem naszej wspólnej pracy. Latem 2016 roku podjęliśmy próbę zbadania zawartości pewnego przedsięwzięcia teoretycznego, prezentującego się jako nowa propozycja filozoficzna z pogranicza materializmu i idealizmu, nowa formuła „materializmu dialektycznego”, którego fundamentalne pytanie brzmi: w jaki sposób podmiotowość powstaje z materii?

Chodziło w punkcie wyjścia o ostatnie książki Slavoja Žižka i przedstawiany w nich zarys teorii genezy podmiotowości, określanej - w kontraście wobec ontologii, teorii „bytu” mianem „denologii”, teorii den. Temu właśnie pochodzącemu od Demokryta neologizmowi poświęcone są nasze teksty, szkicujące jego różne filozoficzne użycia: w atomizmie Demokryta zinterpretowanym przez Heinza Wismanna, w sofistyce Barbary Cassin, która przeniosła interpretację Wismanna na grunt lacanowski, oraz w samej teorii Žižka z książek Less than Notbing i Absolute Recoil.

Jest to druga nasza próba wspólnego mierzenia się z propozycjami „nowych materializmów”: pierwszą jest napisany przez nas obu artykuł poświęcony Quentienowi Meillassoux i jego „materializmowi spekulatywnemu”1. Poddaliśmy go wtedy krytyce, uznając go za niezadowalające rozwinięcie pojęcia „niecałości”, wokół którego skupiały się podzielane przez nas filozoficzne intuicje. Po artykule o Meillassoux, w którym dominuje wymowa negatywna, planowaliśmy - wokół „denologii” - wystapienie bardziej pozytywne.

\footnotetext{
${ }^{1}$ P. Skalski, B. Wójcik, „Kryptologia Meillassoux”, Kronos 3/2016.
} 
Przeliczyliśmy się jednak w optymizmie; rozbieżności, jakie zaistniały między nami w ocenie „denologii” w takim kształcie, w jakim istnieje obecnie, doprowadziły do podzielenia projektu na dwoje, rozłożenia materiału między dwa teksty według kryterium chronologicznego. Nie jest to dwugłos: to zaledwie - z jednej strony - zreferowanie genezy „denologicznego" dyskursu, oraz - z drugiej strony - kreatywna rekonstrukcja pewnej propozycji teoretycznej.

Tym jednak, co łączy w tle oba teksty, pozostaje pojęcie niecałości, warte naszym zdaniem dalszych badań i dalszych teoretycznych eksperymentów. Pojęcie niecałości działa jako spoiwo, które wiąże pewną prawdę dotycząca naszego dzisiejszego doświadczenia z nurtami teoretycznymi - współczesnymi i przeszłymi - które, zgodnie z aspiracjami filozofii, pozwalaja owo doświadczenie (wewnętrznego konfliktu) poddać myśleniu. Teksty o „denologii”, czytane wspólnie, proponuja jeden z możliwych sposobów naświetlenia natury tego spoiwa.

CYTOWANIE: Skalski, Piotr, Wójcik, Bartosz. 2016. Denologia. Słowo wstępne. Praktyka Teoretyczna 3(21): 194-195.

DOI: $10.14746 /$ prt.2016.3.9

AUTHOR: Piotr Skalski, Bartosz Wójcik

TITLE: Dentology. A Foreword

ABSTRACT: A short introduction to the reading seminar on dentology (the ontology of den, of "less than nothing"). 